\title{
51. Studies on the Stratigraphy and Tectonic of the Sakawa Basin in the Outer Zone of Southwest Japan.
}

\author{
By Teiichi KoBayashI. \\ (Comm. by H. YABE, M.I.A., April 13, 1931.)
}

Sakawa Basin in the province of Tosa, Shikoku, is one of the most interesting fields for the study of the geological history of the Outer Zone of Southwest Japan; it is well known among us since the pioneer work of E. Naumann ${ }^{1)}$ early in the Meiji era. The following is the summary of my geological and palaeontological studies in this district during the past six years. The geological formations exposed in the Sakawa Basin and its environs are as follows:

IV. The Monobegawa Series (Albian-Hauterivian), about $700 \mathrm{~m}$. thick.

Bed M3. Sandy shale, with Trigonia longiloba, T. hokkaidoana and other shells; some indeterminable plant leaves found at Miyanohara. Equivalent to the Puzosia shale of the Monobegawa Basin.

Bed M2. Massive sandstone, and sandstone and shale in repeated alternation; Trigonia pocilliformis found in the former at Sendatsuno and Igetani.

Bed M1. Basal conglomerate containing pebbles of Palaeozoic sedimentaries and also of granitic rocks.

III. The Ryoseki-Torinosu Series (Wealden to Middle Jurassic), $600 \mathrm{~m}$. thick.

Bed R3. Shale and sandstone, with plant remains and Purpuroidea sp. at Kurose.

Bed R2b. Soft shale with the Ryoseki flora and fauna; Zamiophyllum buchianum, Gervillia shinanoensis and Corbicula sanchuensis found at Kaisekiyama. The two molluscs are the characteristic members of the Shiroi Group of the Sanchu Ditch in the Kwantô Mountainland.

Bed R2a. Massive sandstone with the same brackish-water fauna as the Bed R2b.

Bed R1. Sandstone, sometimes conglomeratic and sometimes arkose and coarsegrained; with Trigonia naumanni, T. neumayri, Ostrea diluviana, and other shells at Yamanokami and Kamo-hommura.

Bed T3. Soft shale and sandstone, with Trigonia sagawai and other shells at Kanbaradani, and with Onychiopsis elongata and Cladophlebis browniana at Yoshidayashiki and Mimikire.

Bed T2. Shale and sandstone interbedded with lenses of Torinosu limestone containing abundant fossils : foraminifera, stromatoporoids, tabulate corals, haxacorals, cidarids, brachiopods, and calcareous algae; Trigonia toyamai, Lima, Pecten, Pbicatula, Opis, echinoids and some fragmental ammonites.

Bed T1. Sandstone; also conglomerate and breccia.

II. The Sakawa Series (Noric-Ladinic), 350-500 m. thick.

Pseudomonotis Beds (Upper Noric). Shale and Sandstone with Pseudomonotis ochotica. Oxytoma Beds (Lower Noric-Upper Carnic). Sandstone with some thin layers of conglomerate; Oxytoma zitteli, Myoconcha, Pecten, Lima, Avicula, brachiopods and plant remains. There are three fossiliferous beds, Pecten Bed, Myoconcha Bed and Avicula Bed; their mutual relation not yet thoroughly studied.

Halobia Beds (Middle and Lower Carnic). Sandy shale with Yamanba limestone. Halobia charlyana, Paratrachyceras cfr. hofmanni, Spiriferina aff. shalshalensis

1) E. Naumann and M. Neumayr: Zur Geologie and Palaeontologie von Japan. Denksch. d. k.k. Akad., Wien, LVII (1890). 
and Rhynchonella aff. zealandica, besides bryozoa, crinoids, other brachiopods and bivalves, and plant remains. Correlated to the Middle and Lower Carnic of the Himalayan-Mediterranian province through the named species.

Daonella Beds (Ladinic). Sandy shale with Protrachyceras aff. archaelaus, Daonella indica and other species of the same genus.

II A. Togano Series (Triassic, also possibly including Lower Jurassic).

A complex of sandstone, shale, and quartzite, with intercalated limestone and hornstone; Pecten suzukii nov. indicating Carno-Noric age found at the Togano pass. The Sambosan limestone with the fossils of Ladino-Carnic age lies in the eastern prolongation of the zone occupied by this series. Its upper and lower limits being at present unknown, this series is now taken tentatively as "pre-Torinosu and post-Chichibu."

\section{Upper Chichibu Series (Permo-Carboniferous).}

A thick complex of shale, sandstone, quartzite, schalstein, limestone and radiolarian chert; the limestone in lenses contains frequently Fusulina, Lonsdaleia etc. Many interesting forms of sponges, crinoids, corals, etc. are collected in the limestone of Shimoyama Klippen.

The faunas of the Daonella and Halobia Beds are intimately related to those of the Himalayan-Mediterranean province, while the Pseudomonotis Beds have the well known Upper Noric form, Pseudomonotis ochotica, of the Arcto-Pacific province. The Oxytoma Beds are important for the Triassic history of the eastern Asia in representing an intermediate stage in the faunal change from the Himalayan-Mediterranean type to the Arcto-Pacific.

As to the lithological facies, it must be pointed out that the sediments of the Sakawa Series are markedly different from those of the Togano Series and rather resemble the contemporaneous deposits of the Inner Zone of Southwest Japan. The Sakawa Series as well as the Torinosu Series is purely marine in origin, being characterised by limestone-reefs in lenses. On the other hand, the Ryoseki Series consists of sediments in regression-facies between the Jurassic and Cretaceous periods, and has marine-, brackish-water and fresh-water deposits in irregular alternation, as once thoroughly discussed by Professor Yabe,") while the Monobegawa Series is a product of the early Cretaceous marine transgression. By the way, it will be noted that the Jurassic Toyora-Tetori Series, of the Inner Zone consists of basin deposits on land, with but little influence of ingressing sea water.

In the other parts of Japan, it is often stated that some stratigraphical discordances are visible between the Torinosu and the Ryoseki, and also between the Ryoseki and the Monobegawa; but in the Sakawa basin, the former discordance is imperceptible, whereas the latter is fairly distinct, as stated above. Broadly speaking, these discordances do not suggest any intense orogenic movements, being nothing but the results of marine regression and local warping. On the other hand, a discordance of the first order of magnitude occurred

1) H. Yabe: Cretaceous Stratigraphy of the Japanese Islands. Sci. Rep. Tohoku Imp. Univ., Sendai (Geol. Ser.), Vol. XI (1927). 
in my opinion, between the Lower and Upper Cretaceous deposits, at least in the Outer Zone of Southwest Japan.

Tectonically, the Sakawa Basin is, as in the Ryoseki, Monobegawa, Katsuragawa and Yuasa Basins, bounded by thrusts on the northern and southern sides, as shown in the Profile A. To the south of the southern thrust (the Butsuzo-Itogawa Line), ${ }^{1)}$ there is a thick complex mainly of the Mesozoic deposits, of which the precise age is still unknown, covering a wide area. It consists of sandstone, and shale, in repeated alternation and intercalating quartzite, chert, and a few limestone lenses.

The Monobegawa Series in the northern part of the Sakawa Basin shows a synclinal structure and is bounded by the Chichibu Series overthrusted from north. On the southern side, it overlies disconformably the Ryoseki-Torinosu Series, which is cut by a later dislocation in the equatorial direction, so that the base of the latter series is concealed.

Very fossiliferous Triassic deposits are well developed in the central part of the Sakawa Basin, where some patches of a chertbearing series are found. Whether this series is Triassic or Palaeozoic has long been disputed; but it is now found to be Palaeozoic in age and the keen insight of Dr. Naumann in this connection is verified, as a few lenses of Fusulina limestone have been discovered in it. It is usually in thrust-contact with the other series of the Sakawa Basin.

It is of special interest that there exist two "Klippen" of the Permian rocks in the Sakawa Basin, which I am used to call "Suemitsu Klippen and Shimoyama Klippen." Both are rootless and rest on a foundation of the Sakawa Series.

In the southern part of the Sakawa Basin, the Ryoseki-Torinosu, Togano, and Chichibu series are found in regular order from north to south, all dipping to the north, though some minor folding and thrusting are recognised.

The Chichibu Series is thrusted upon Mesozoic rocks to the south of it along the Butsuzo-Itogawa Line; among the latter there is Torinosu limestone exposed at Butsuzo and some other spots. On the other hand, the Ryoseki-Torinosu Series lies beneath the Chichibu Series thrusted from the north, as well visible at Ôhirayama where the Neoschwagerina limestone lies upon the Torinosu-Ryoseki Series with the boundary plane dipping to north in an angle of about $40^{\circ}$.

We learn from the evidences mentioned above that the Sakawa Basin shows an imbricate structure composed of three Nappe, of which the northern one consists of two Klippen, already cited. At present it

1) Refer to my paper, Note on a New Occurrence of Ladino-Carnic Limestone at Sambosan, Tosa Province. Jap. Jour. Geol. \& Geogr., Vol. VIII (1931). 
is still unsettled whether the Sakawa Series is exotic or authochthonous ; if exotic, it is by no means improbable that reversing of strata occurred in a considerably large scale as shown in the Profile B. The marked difference in facies between the Sakawa Series and the Togano Series, exposed side by side within a short distance, and the reef-like condition of some lenses of the Torinosu limestone are more easily explained by this interpretation than the other as shown in the Profile A. It must be also added that certain ultrabasic and granitic rocks intruded along the northern dislocation line of the northern Nappe and its vicinity in the course of overthrusting movement from north to south.

"Imbricate structure" was sometimes used by several authors for the interpretation of the geological structure of the Outer Zone of Southwest Japan, but the precise mode of imbrication or overthrust has not yet been thoroughly studied by any body. As stated above, the true nature of this structure is now brought to light in the Sakawa Basin lying to the north of the Butsuzo-Itogawa Line.

The climax of the late Mesozoic crustal disturbances resulted in the Deckenbau in a miniature scale in the Sakawa Basin is undoubtedly post-Monobegawa in age; but its more accurate date can not be settled from the present material of observation in the Sakawa Basin, where any younger Mesozoic and older Cenozoic deposits (or in short the "cover") are lacking. Since the formation of the Deckenbau, some dislocations of little importance took place in equatorial direction; moreover there are some meridional dislocations perhaps of Tertiary age.

Finally I wish to express my sincere thanks to Professor Yabe for his kind reading of this paper and criticism on several points.

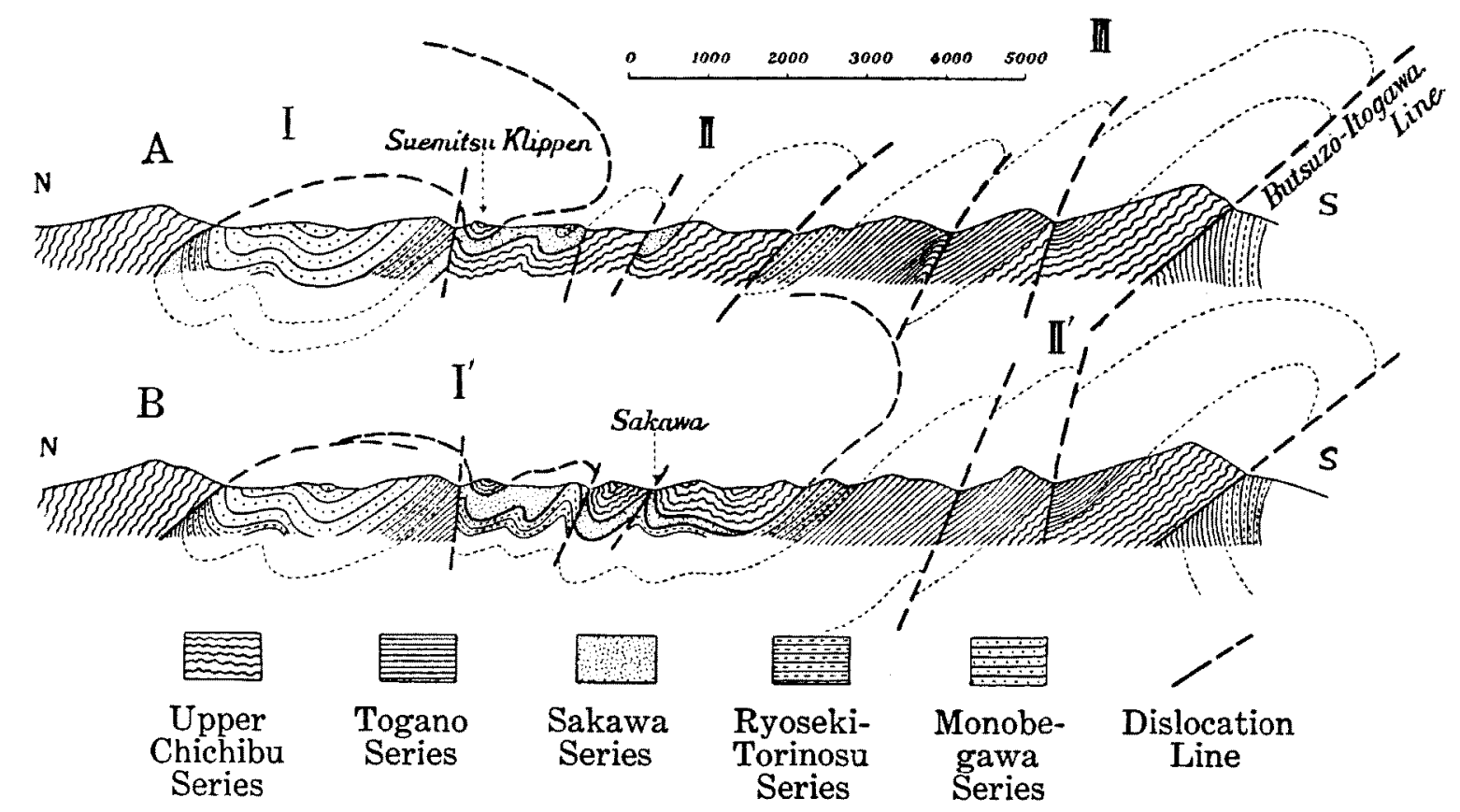

